Copyright (C) 2021 by Cherkas Global University

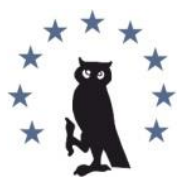

Published in the USA

Voennyi Sbornik

Has been issued since 1858 .

E-ISSN: 2409-1707

2021. 9(2): 121-134

DOI: 10.13187/vs.2021.2.121

https://vs.cherkasgu.press

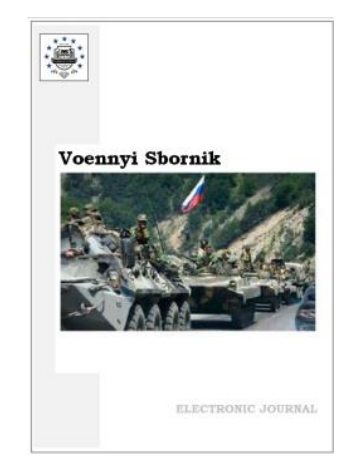

\title{
The Experience of the Combat Use of Unmanned Aerial Vehicles in Recent Conflicts According to Electronic Media
}

Irek A. Solovatov a

a Kalashnikov's Izhevsk State Technical University, Russian Federation

\begin{abstract}
At the moment, unmanned aerial vehicles are an actively developing system of weapons, possibly forming into a new branch of the military in the near future. The absence of a pilot allows not only to reduce the weight and dimensions of the apparatus, but also to reduce its cost. And the operator on the ground gets the opportunity to perform much more daring dangerous actions than manned vehicles.

The paper provides an overview of the features and results of the combat use of unmanned aerial vehicles in recent armed conflicts. The description of the Turkish UAV "Bayraktar" and the ammunition carried by it is given. The results of its application in the conflict in NagornoKarabakh, the operation "Spring Shield" and the civil war in Libya are presented in a concise form. A description of the "Tomahawk" cruise missile and the results of its use in Syria are given. The work was written on the basis of publicly available electronic media. vehicle.

Keywords: conflict, combat experience, anti-aircraft missile system, unmanned aerial

\section{1. Введение}

На данный момент во всех передовых армиях мира стремительно зарождается новый род войск. Небольшие летательные аппараты постепенно вытесняют многие современные виды пилотируемых летательных аппаратов.

За последние десятилетия беспилотные летательные аппараты (БПЛА) не просто эволюционировали, а превратились из средств разведки и наблюдения в полноценные боевые воздушные средства. Они сравнительно недорогие, обладают высокой мобильностью и могут решать широкий спектр задач от разведки до нанесения высокоточных ударов.

Беспилотный летальный аппарат обладает рядом преимуществ. Он как боевая единица не требует больших затрат при производстве, амортизации и техническом обслуживании с минимальным материально-техническим оснащением. В отличие от пилотируемых боевых истребителей, штурмовиков и бомбардировщиков БПЛА не требуют длинных взлетнопосадочных полос с твердым покрытием со сложной аэродромной инфраструктурой. Для взлета и посадки БПЛА достаточно небольшого прямолинейного участка асфальтированной дороги шириной 20-30 м. Это качество позволяет обеспечить высокую мобильность развертывания, гибкую оперативность действия при меняющейся боевой обстановке.

Отсутствие пилота позволяет значительно уменьшить массу и размеры планера. Уменьшение размеров планера позволяет увеличить его аэродинамическое качество, уменьшить лобовое аэродинамическое сопротивление и эффективную площадь рассеивания поверхностей. Перечисленные выше факторы приводят к тому, что БПЛА обладают простой
\end{abstract}


относительно пилотируемых боевых самолетов конструкцией. А простота конструкции в свою очередь обеспечивает высокую технологичность и простоту производства.

Эти факторы позволяют в больших количествах, на порядок превышающих скорость выпуска пилотируемых боевых самолетов, выпускать относительно дешевые боевые единицы, не уступающие по своим боевым качествам самолетам штурмовой и тактической авиации.

Следует заметить, что в военной промышленности многих стран четко отслеживается тенденция к удешевлению исполнения сложнейших технологических процессов таких как аддитивные технологии, производство микроэлектроники и композиционных материалов. Причиной удешевления сложных техпроцессов является активное внедрение новейших систем автоматического проектирования (САПР), систем планирования и организации производства на основе искусственного интеллекта. Соответственно, дорогие и сложные в производстве БПЛА становятся дешевле с каждым годом.

И если сейчас количество ударных БПЛА в самых современных армиях мира не превышает нескольких сотен, а цена каждой боевой единицы ударно-разведывательных БПЛА составляет миллионы долларов. То пройдет несколько десятков лет и новые технологии дадут возможность производить десятки, сотни тысяч боевых машин, звено которых по своей боевой эффективности будет сопоставимо по боевой эффективности современному штурмовику Су-25. Страна, первая освоившая эти технологии получит неоспоримое превосходство и инициативу на поле боя.

Даже без применения роботизированного искусственного интеллекта БПЛА обладают другим значительным преимуществом перед пилотируемыми летательными аппаратами. В отличие от пилотируемых машин оператор БПЛА гораздо меньше рискует жизнью, что дает ему возможность проводить безнаказанную компьютерную игру против живых людей и техники противника.

Оператор пилотируемой машины трижды подумает, прежде чем выполнять задание с высоким риском не вернуться с задания. И лишь самые смелые и хладнокровные люди могут решиться на подобные самоубийственные задания.

Примером таких боевых вылетов с очень высоким риском не вернуться являются бомбардировки Берлина, осуществленная ВВС РККА в августе и сентябре 1941 г.

Другой пример это осуществленная в июне 1981 г. израильская бомбардировка иракского ядерного центра «Озирак», на котором по данным израильских спецслужб диктатор Саддам Хусейн собирался наладить производство оружейного плутония. Истребители должны были незамеченными для наземных наблюдателей и РЛС на сверхмалой высоте в условиях гористой местности пролететь над территорией Саудовской Аравии, глубоко залететь вглубь территории Ирака, сориентироваться на местности, найти цель, нанести удар и, избегая встречи с истребителями ВВС Ирака, вернуться обратно на авиабазу Неватим в пустыне Негев.

Теперь же при проведении таких рискованных операций, в случае сбития, оператор машины не гибнет и его, спустя некоторое время, можно снова привлечь к управлению уже другой машиной. В то время как в случае смерти или пленения оператора пилотируемой машины государство теряет десятки миллионов долларов, потраченных на его обучение.

Ничтожный шанс погибнуть позволяет пилоту принимать более рискованные решения и самые смелые атаки при решении боевых задач. К таким задачам относится полет на сверхмалых высотах с риском разбить машину, разведка в глубоком тылу противника, где при сбитии у обычного пилота не было бы шансов избежать плена; работа в глубокоэшелонированной системе ПВО, таких как израильская система ПВО «Железный купол» или система ПВО Калининградской области.

Еще более опасным это оружие будущего делает гипотетическая возможность применения высокоточных тактических ядерных боеприпасов и снарядов с химическим и биологическим оружием. Удар тактическими ядерными боеприпасами малой мощности позволит без сильного ущерба окружающей среде наносить эффективные удары по подземным бункерам и командным пунктам, портам, аэродромам, мостам, транспортным узлам, крупным скоплениям живой силы противника.

Применение высокоточных тактических ядерных боеприпасов сделает бесполезными танки, самоходную и буксируемую артиллерию подобно тому, как пулемет и колючая 
проволока положили конец кавалерии. Также бесполезными станут многие подземные укрепления бункерного типа.

Беспилотные летательные аппараты являются одним из самых перспективных направлений. И значение этого направления для военной отрасли переоценить сложно.

\section{2. Обсуждение и результаты}

\section{БПЛА ТВ2 «Вауraktar»}

Турецкие военные, опираясь на опыт Американской военной интервенции в Ираке и Афганистане, видели насколько эффективным и опасным оружием могут быть ударноразведывательные БПЛА. И захотели закупить партию БПЛА MQ-9 «Reaper», чтобы воевать с Курдскими боевиками из YPG и Рабочей партии Курдистана (РПК). Однако Американцы категорически отказали Туркам из-за территориального конфликта с другим членом НАТО Грецией по поводу Северного Кипра и из за того, что турки борются с курдскими сепаратистами, которых США считает союзной силой в борьбе с Башаром Асадом и радикальными группировками в Ираке и Сирии. Израиль также категорически отказался продавать свои БПЛА «Heron» и «Hermes-9o0» из-за натянутых отношений с официальной Анкарой.

И тогда турки решили создать свой ударно-разведывательный БПЛА. За разработку нового Турецкого БПЛА ТВ2 «Bayraktar» взялся зять президента Турции Сельджук Байрактар и его компания Baykar Makina. Он с детства увлекался авиамоделированием и на деньги своего отца Оздемира Байрактара получил высшее техническое образование в Пенсильванском и Массачусетском университетах, защитившись на степень кандидата наук $\mathrm{PhD}$.

Первый летный экземпляр ТВ2 поднялся в воздух в августе 2014 г. В декабре 2015 г. в сети появился ролик, где ТВ2 на полигонных испытаниях ведет прицельный огонь управляемой противотанковой ракетой CIRIT.

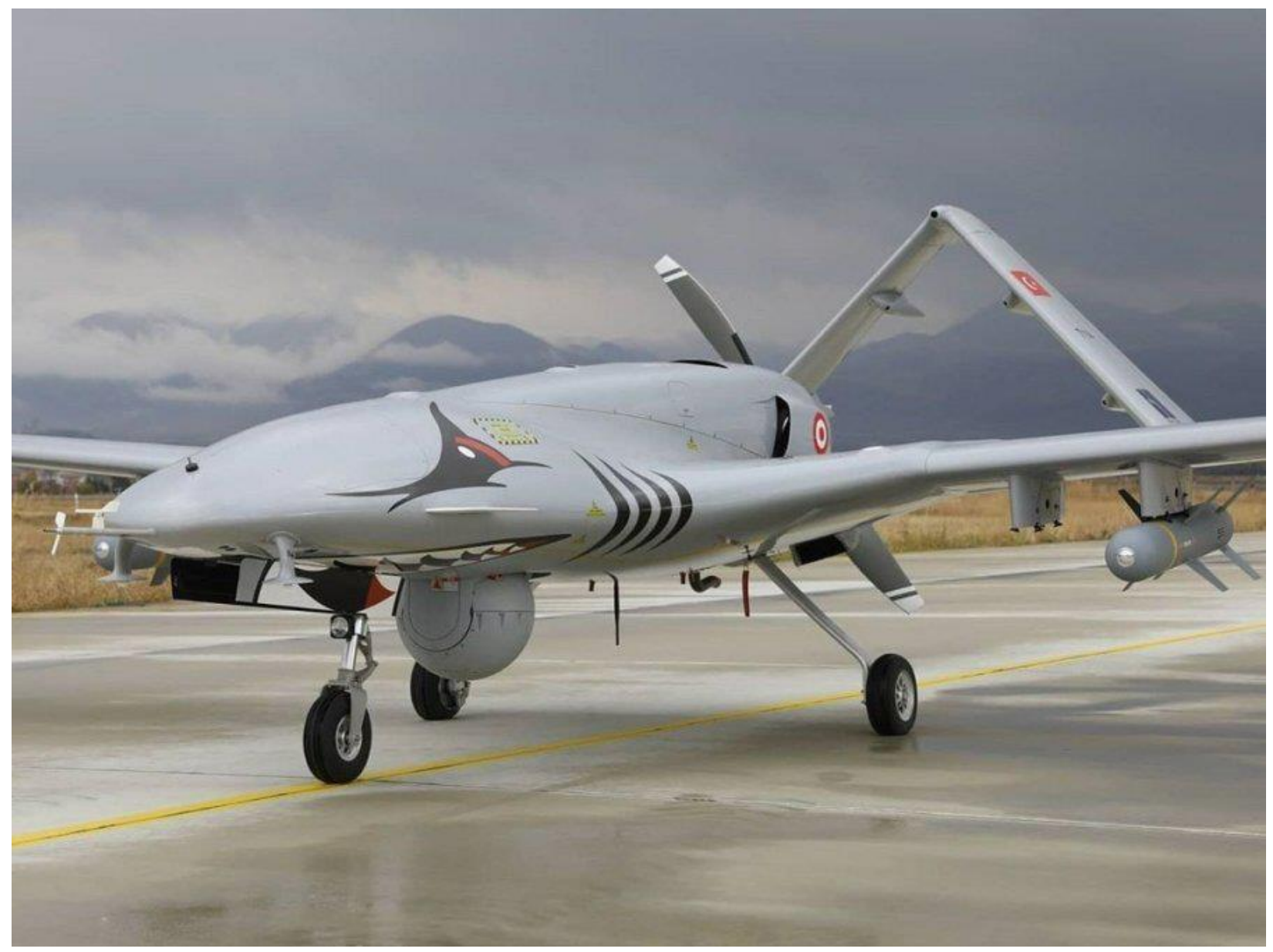

Рис. 1. Внешний облик БПЛА ТВ2 «Bayraktar» 
Планер ТВ2 выполнен по классической самолетной аэродинамической схеме - крылья впереди стабилизаторов. Хвостовая часть выполнена по двухбалочной схеме как на немецком тактическо-разведывательном самолете Focke-Wulf FW-189 «Uhu». Такая схема позволяет сохранять управляемость планера на низких скоростях. Хвостовые килевые рули соединены с обратным наклоном, образуя единую конструкцию.

Конструкция крыла обеспечивает высокое аэродинамическое качество планера. Высокое аэродинамическое качество планера, в свою очередь позволяет беспилотнику подобно сове подолгу «зависать» в воздухе при малых оборотах двигателя. Это позволяет максимально снизить звук работающего двигателя, чтобы подкрасться к противнику на большой высоте и нанести по нему внезапный удар бесшумными управляемыми свободно падающими снарядами.

В качестве движителя используется толкающий винт, расположенный между хвостовыми балками. Поток воздуха попадает на хвостовое оперение, что должно увеличить управляемость и маневренность машины. Силовая установка представляет собой четырехцилиндровый ДВС австрийского производства Rotax 912. Мощность мотора при этом небольшая - всего 100 л.с. при объеме 1,2 литра. Для регулирования частоты оборотов двигатель управляется редуктором. Охлаждение цилиндров жидкостное, так как на малых скоростях встречные потоки воздуха не позволяют обеспечить достаточное теплоотведение (Турецкий БПЛА).

Конструкция планера и характеристики двигателя обеспечивают поднятие в воздух 150 кг полезной нагрузки, при весе укомплектованного и заправленного БПЛА $500 к г$.

Бортовое радиоэлектронное и навигационное оборудование, а также средства наблюдения для БПЛА ТВ2 закупаются и производятся на заказ в Германии, Канаде и США.

Крылья оснащены четырьмя специальными подвесками для боеприпасов. Они приспособлены для закрепления корректируемых боеприпасов. Сами боеприпасы оснащены двумя системами наведения на цель. Одна из них по лазерному лучу, вторая инерциальная. Инерциальная система обеспечивает КВО 3 м.

Для нанесения ударов БПЛА ТВ2 использует следующую номенклатуру боеприпасов:

UMTAS - (тур. Uzun Menzili Tankisavar Sistemi, дословный перевод - дальнобойная противотанковая система) турецкая противотанковая управляемая ракета с лазерным и инерциальным наведением. Масса 37,5 кг, длина 1750 мм, калибр 160 мм. Ракета является универсальным оружием и способна вести борьбу не только с вражескими танками. Техническая возможность ПТУP UMTAS работать по схеме «выстрелил-забыл» делает ее крайне удобной для борьбы с ЗРК, так как позволяет обстреливать их из укрытий, в то время как ЗРК не способны вести прицельный огонь по целям, скрытым в складках местности. Также такая система позволяет БПЛА ТВ2 выпустить синхронно все четыре ракеты по ЗРК, что сильно осложнит их сопровождение и перехват. Является аналогом американской ракеты AGM-114 «Hellfire». Максимальная скорость составляет 425 м/с, эта характеристика делает ПТУР UMTAS идеальным оружием для борьбы с ЗРК за счет маленького подлетного времени.

Roketsan MAM-L - корректируемая планирующая бомба. Масса 21,5 кг, калибр 160 мм. Боевая часть может иметь противотанковое, термобарическое и противопехотное исполнение. Дальность полета 8 км. Представляет собой укороченный до длины в 1000 мм боеприпас турецкого ПТУP UMTAS без твердотопливного двигателя. Управление осуществляется хвостовым оперением.

Roketsan MAM-C - корректируемая планирующая бомба. Масса 7 кг, калибр 70 мм. Представляет собой укороченную версию ракеты CIRIT. Головная часть представляет собой классический фугасный боеприпас. Дальность полета 8 км. Предназначена для атаки слабоукрепленных укрытий и живой силы противника. Также она идеально подходит для повреждения и снятия динамической защиты танков противника, без которой танк, имеющий слабое бронирование в верхней проекции становится легкой мишенью для более тяжелых боеприпасов MAM-L и UMTAS с кумулятивной головной частью (Турецкий БПЛА).

Боеприпасы Roketsan MAM-C и MAM-L обладают достаточно высокой точностью, позволяющей наносить точечные удары. Так эти системы могут быть использованы против военных целей, прикрывающихся гражданскими объектами.

Отсутствие двигателя делает боеприпас Roketsan MAM-L и Roketsan MAM-C бесшумным оружием. Применение данного боеприпаса сделало «Байрактары» не только 
идеальным оружием истребительной войны и убийцей пехоты с бронетехникой, но и эффективным психологическим оружием. Если артиллерийский или минометный обстрел сопровождается световыми и шумовыми эффектами и у противника есть время скрыться в блиндаже с укрепленными перекрытиями, то дроны ТВ2 несут смерть и тяжелые ранения незаметно. К тому же в случае со ствольной артиллерией и минометами первые выстрелы являются пристрелочными. Артиллеристы используют прием «вилка» для того чтобы поймать цель противника, что дает противнику дополнительные секунды чтобы спрятаться в укрытие. А здесь противник узнает о начале атаки только после первых взрывов. Беспилотник как тихая сова бесшумно уносит жизни людей.

Невидимый противник может прилететь с любой стороны и нанести удар в любое время. Он как снайпер заставляет противника не вылезать из укрытий, подрывает его боевой дух, вводя в состояние стресса, сменяемого полной апатией и нервным истощением.

Вместе с сильными сторонами для объективной оценки нужно отметить и слабые стороны БПЛА TB2 «Bayraktar». Такой его слабостью является, прежде всего, отсутствие средств защиты от вражеской авиации, таких как ракеты класса «воздух-воздух». Другая слабость это слишком маленькая скорость полета 120 км/ч и маленький практический потолок. Его, в случае обнаружения легко могут перехватить даже самолеты Великой Отечественной войны, начиная с биплана И-15, заканчивая Ла-7 и Як-9, не говоря уже о современных истребителях и перехватчиках. Многие военные эксперты полагают, что ТВ2 эффективен только в условиях полного превосходства в воздухе или локальных конфликтах, и что в глобальной войне между сверхдержава они понесут тяжелые потери и перестанут летать.

\section{Применение БПЛА в Нагорно-Карабахском вооруженном конфликте}

Как обычно для мировой истории полигоном для испытания нового турецкого оружия стала горячая точка. И этим полигоном, этой очередной горячей точкой стал разгоревшийся в конце сентября 2020 г., тянущийся тлеющий с конца 80-х гг., территориальный конфликт между Арменией и Азербайджаном за спорную территорию Нагорно-Карабахской республики.

27 сентября 2020 г. из пограничных столкновений и провокаций конфликт между бывшими советскими республиками перетек в обстрелы территорий, а затем в самую настоящую войну с массовым применением реактивной, ствольной артиллерии, моторизованных и танковых соединений с привлечением десятков тысяч военнослужащих. И с самого начала ведения боевых действий инициатива была на стороне ВС Азербайджана.

Эта война не была похожа на локальные конфликты на постсоветском пространстве, такие как в Приднестровье, грузино-абхазские и грузино-осетинские конфликты, гражданская война в Таджикистане, Первая чеченская война, вооруженный конфликт на юго-востоке Украины и Первая война в Нагорном Карабахе. В отличие от всех этих конфликтов эта война носила молниеносный характер и закончилась также быстро, как и началась.

Первая и Вторая война в Нагорном Карабахе отличались друг от друга примерно таким же образом, как позиционная война на Западном фронте в Первую Мировую Войну 19141918 гг., где воюющие стороны, истекая кровью, пытались сдвинуть линию фронта на несколько километров; и французская компания вермахта мая-июня 1940 г., когда немецкие танковые армии, обойдя линию Мажино через Бельгию и пройдя через Арденнские горы, за 12 дней ожесточенных боев вышли к поливу Ла-Манш, окружив и практически уничтожив крупнейшую армейскую группировку французов, англичан и бельгийцев во Фландрии и под Дюнкерком. В первом случае (1992-1994 гг.) мы видим затяжную войну на истощение, а во втором молниеносную войну с упором на применение самых передовых вооружений. Как и Французская кампания вермахта Вторая война в Нагорном Карабахе длилась 44 дня.

Вместо того чтобы атаковать хорошо укрепленные и пристрелянные позиции НКР в гористой местности, Азербайджан сделал ставку на изнуряющую истребительную войну с массовым применением БПЛА.

В ходе истребительной войны на истощение Азербайджан намеревался точечными ударами методично подавлять системы ПВО противника. А после уничтожения большей части средств ПВО, такими же точными ударами концентрировать тихую огневую мощь на 
бронетехнике, артиллерии, транспортных средствах, объектах инфраструктуры, складах, командных пунктах и живой силе противника.

Ударной силой наступления и ключевым фактором успеха азербайджанской стороны стали закупленные в режиме строгой секретности турецкие БПЛА Anka-S и TB2 «Bayraktar», а также израильские барражирующие боеприпасы «Нагор».

БПЛА не только находили цель для артиллерии и собирали разведданные для наступающих сухопутных частей, например, находили проходы в минных полях, но также сами достаточно эффективно методично расстреливали танки и другую бронетехнику противника высокоточными турецкими боеприпасами UMTAS, MAM-C и MAM-L.

Танки Т-72 армии НКР, имея слабую броню и динамическую защиту в верхней проекции, были практически беззащитны перед управляемыми противотанковыми кумулятивными боеприпасами.

И эта стратегия неожиданно полностью себя оправдала. Азербайджан прорвал фронт на юге НКР и уже на десятые сутки боевых действий с минимальными потерями занял населенные пункт Джебраил и далее в короткий срок с боями занял прилегающие к нему высоты и населенные пункты, имеющими чрезвычайное стратегическое значение.

Все контрнаступления армянской стороны становились провальными - ударные группировки танковых и моторизованных соединений, усиленных пехотой попадали под ураганный огонь реактивных и ствольных артиллерийских систем, корректировка огня которых производилась с помощью БПЛА.

С минимальными потерями вооруженные силы Азербайджана заняли ключевые населенные пункты и господствующие над местностью высоты, нанесли тяжелейшие потери и подорвали боевой дух вооруженным формированиям НКР, вернув территории, отнятые Арменией у Азербайджана в 1994 г. по итогам Первой Нагорно-Карабахской войны.

В течение 44 дней войны, по заявлениям своих официальных представителей, вооруженные силы Азербайджана уничтожили 5 единиц ЗРК 9К331 «Тор-М2КМ», 4 единицы ЗРК 2К12 «Куб», 40 единиц ЗРК 9К33 «Оса» различных модификаций и даже один ЗРК С-300.

\section{Операция «Весенний Щит»}

Первым успешным применением стаи ударных БПЛА против ЗРК стала турецкая военная операция «Весенний щит» на севере Сирийской арабской республики.

Весной 2020 г., открыто встав на сторону Сирийских мятежников из Свободной сирийской армии, Анкара ввела кадровые армейские части в Сирийскую провинцию Идлиб. Применяя беспилотники для борьбы с сухопутными частями и живой силы САР, турки смогли обескровить наступающие сирийские части и посеять среди них панические настроения, остановив тем самым успешно начавшуюся наступательную операцию сирийцев.

Беспилотники наносили удары и возвращались на базы быстрее, чем до них с авиабазы в провинции Хомс долетали истребители ВВС САР.

Для отражения массированных атак БПЛА сирийские военные были вынуждены в срочном порядке отправить на фронт сохранившиеся в арсенале зенитные комплексы войсковой системы ПВО, в том числе современные ЗРПК российского производства «Панцирь-С1».

По словам турецких военных в ходе боев им удалось уничтожить 4 ЗРПК Панцирь-С1. В свою очередь, по данным независимого сирийского военного обозревателя Syrian MC, зенитные комплексы произвели 25 пусков ракет и поразили 20 БПЛА, официальные представители Министерства обороны Турции подтвердили поражение 12-ти из них.

\section{Потери ЗРПК «Панцирь-С1» в Ливийской гражданской войне}

Положительно оценив итоги применения БПЛА «ayraktar» в военной операции «Щит Евфрата» 2018 г. против военизированных формирований курдов на севере Сирии, турецкие военные решили испытать их в бою против Ливийской национальной армии Халифы Хафтара.

С 2019 г. Турция регулярно отправляла различную военную технику, в том числе неизвестное количество беспилотников, признанному ООН Правительству национального согласия (ПНС) Ливии во главе с Фаизой Сараджем, находящемуся в Триполи. 
Фаиз Сарадж является бескомпромиссным политическим оппонентом Хафтара. С 2016 по 2021 гг. в Ливии наблюдалась ситуация двоевластия и войны между этими двумя группировками. В прозападном и протурецком правительстве Сараджа доминирующую роль играли террористические организации и многие запрещенные в России группировке, в их числе «Братья-мусульмане». Его правительство выступало за исламский путь развития и построение законодательства Ливии на основе законов Шариата. Хафтар же выступает за умеренный светский путь развития страны (Почему Панцири...).

Противоречия между сторонами конфликта были столь бескомпромиссны, что во время переговоров в Москве Хафтар и Сарадж отказались садиться за один стол для переговоров. В ноябре 2020 г. силы Ливийской национальной армии контролировали 80 \% территории Ливии и вышли к пригородам Триполи. Между сторонами начались переговоры, Сарадж покинул страну, в Женеве инициативными группами было создано Временное правительство, гражданская война в Ливии закончилась.

В ходе эпизодических столкновений армия Халифы Хафтара потеряла 9 единиц ЗРПК «Панцирь-С1» российского производства, уничтожив при этом 47 единиц БПЛА ТВ2 «Bayraktar» (В Ливии...).

По результатам этих боев в конце февраля 2021 г. в отчете Объединенного центра передового опыта воздушных сил HATO JAPCC (Joint Air Power Competence Centre) Российские ЗРК «Панцирь» назвали «идеальным средством борьбы против военных БПЛА» (Стало известно...).

В целом ЗРПК Панцирь достаточно неплохо зарекомендовали себя как средство борьбы с ударно-разведывательными БПЛА, однако понесли неоправданно большие потери.

\section{Крылатая ракета BGM-109}

Наряду с беспилотниками другим не менее эффективным высокоточным оружием, способным прорывать районы действия ПВО являются крылатые ракеты.

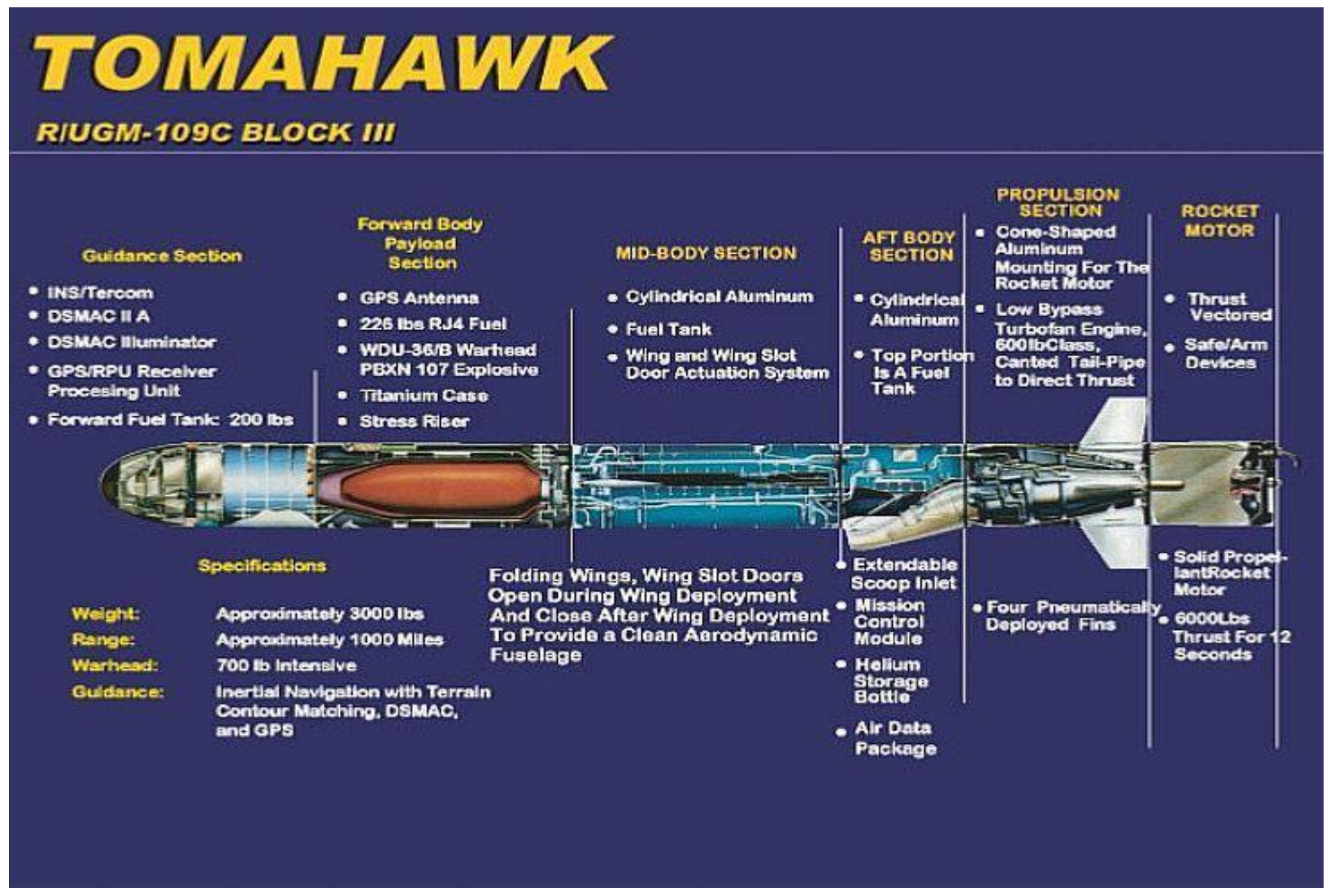

Рис. 2. Компоновочная схема KP BGM-109 «Tomahawk» 
Самой известной крылатой ракетой в настоящее время является BGM-109 «Tomahawk», которая вот уже больше тридцати лет участвует во всех крупных военных операциях ВС США. Всего за три десятилетия американцы и их союзники по Североатлантическому альянсу осуществили 2300 боевых запусков. К примерам достаточно эффективного применения «Томагавков» можно отнести войну в Персидском заливе 1991 г., операции НАТО в Югославии, проводимые с 1995 по 1999 гг., Иракскую кампанию 2003 г. и военные операции НАТО в Ливии в 2011 г.

Так например, в ходе воздушной операции против Ливии в 2011 году, ударами 114 «Томагавков» ВМФ Великобритании на аэродромах базирования была уничтожена практически вся Ливийская авиация («Уроки» ракетного удара...).

C самого своего рождения в конструкторских бюро корпорации Raytheon, крылатые ракеты BGM-109 семейства «Tomahawk» разрабатывались как высокоточное средство прорыва эшелонированной противовоздушной обороны СССР и других стран Организации Варшавского договора. Опыт Вьетнамской войны (1965-1973 гг.) и войны Судного дня (1973 г.) показал, что главной уязвимостью советских РЛС и ЗРК является их низкая способность обнаруживать, сопровождать и сбивать низколетящие цели.

Исходя из этого, американские военные задались целью создать беспилотное высокоскоростное высокоточное оружие, способное на достаточно высокой скорости «подкрадываться» к атакуемой цели и, миновав зону действия РЛС и ЗРК, наносить высокоточные удары в тылу противника.

Для этих целей «Томагавк» выполнен по самолётной компоновочной смехе «моноплан» с раскладными крыльями и крестообразным оперением. Корпус выполнен из композитных материалов, покрытых радиопоглощающим покрытием. Сделано это с целью максимально уменьшить эффективную площадь рассеивания (ЭПР) или способность отражать радиоволны в сторону их источника. Низкая ЭПР позволяет «Томагавку» сливаться с объектами на фоне земной поверхности и быть малозаметным на фоне неба.

Старт производится с ракетных крейсеров типа «Тикондерога» (122 КР на борту), эсминцев типа «Арли Бьёрк» (90...96 КР) и «Зумвольт» (80 КР), а также торпедных аппаратов подводных лодок типов «Огайо» (54 КР), «Вирджиния»(50 КР), «Сивулф» (50 КР), «Лос-Анджелес» (49 КР) (Удар по России...).

В частности, для стрельбы из торпедного аппарата, калибр ракеты, как и у торпед, составляет 533 мм. После выпуска ракеты из контейнера разгонный блок разгоняет ракету. По достижению достаточной скорости включаются турбореактивные двигатели.

Слабым местом крылатых ракет «Томагавк» является их неспособность защититься от самолетов противника в случае обнаружения и неспособность уклоняться от ракетных атак из-за низкой маневренности планера и отсутствия возможности отстрела дипольных отражателей и тепловых ловушек в качестве пассивных помех, как это реализовано на боевых самолётах. Отсутствие плоских сопел делает аппарат очень заметным на фоне земли в ИК-диапазоне.

Сильной стороной является способность наносить точные и незаметные удары по стратегически важным объектам противника. Так во время бомбардировок НАТО Югославии в 1999 г. ударами крылатых ракет были уничтожены центры принятия решений, телекоммуникации, мосты, нефтехранилища, выведено из строя 70\% энергосети, что привело к отключению югославской системы ПВО и погрузило страну в темноту.

Самой сложной частью «Томагавка» является его бортовое радиоэлектронное оборудование. Схема управления и наведения КР «Томагавк» представляет собой сложную комбинацию инерциальной, спутниковой, электронно-оптической корреляционной системы и системы пространственной ориентации по контуру рельефа местности.

Система инерциального наведения - сопровождает полет ракеты большую часть времени. Она включает бортовую ЭВМ, инерциальную платформу, барометрический высотомер и три гироскопа для измерения угловых отклонений и трех акселерометров для измерения ускорений по осям OX, OY, OZ в пространстве.

Спутниковая система навигации - представляет собой военную версию системы глобального позиционирования (англ. GPS - Global Positioning System) или NAVSTAR (англ. NAVigation Satillites providing Time and Range). Принцип ее действия основан на эффекте Доплера - при удалении спутника частота принимаемого сигнала 
уменьшается, при приближении увеличивается. По величине рассогласования частот сигналов с эталонной частотой определяется расстояние до спутников. Оценив расстояние до трех ближайших спутников и, зная их местоположение на средней околоземной орбите по специальной базе данных «Альманах» система с погрешностью 1...7 м определяет свое точное местоположение по широте и долготе. Сигнал GPS находится в дециметровом диапазоне $3 \ldots 6$ ГГц, этот фактор имеет как свои достоинства, так и недостатки. К достоинствам можно отнести высокую пропускную способность каналов связи, а к недостаткам то, что длина волны не дает ей возможности проникать под земную поверхность и толстые бетонные перекрытия.

Среди людей, увлекающихся военной историей, популярен миф, что во время бомбардировок НАТО Югославии в 1999 г. «Томагавки» сбивали с курса магнетронами от бытовых CBЧ печей. Однако, военная версия GPS, вопреки многим мифам, имеет высокую степень защиты от радиопомех, и все подобные мифы являются не подтвержденными никакими доказанными фактами слухами.

Достигается высокая помехозащищенность за счет того, что радиоприемник военных GPS имеет широкодиапозонную частотную модуляцию сигнала. И, следовательно, поставить помехи на весь диапазон является весьма затруднительной задачей. Бортовой компьютер попросту отсеет и сгладит радиошум, получив адекватный сигнал. К тому же в случае войны спутники перейдут на секретные литерные частоты, и системам РЭБ будет достаточно трудно определить их. На КР «Томагавк» применяется и другой способ защиты от помех со стороны РЭБ. Дополнительным способом обеспечить помехоустойчивость является применение приемных антенн с управляемой диаграммой направленности CRPA (Controlled Reception Pattern Antenna). Антенна просто не будет принимать сигналы с направлений, на которые не направлены лепестки диаграммы направленности.

Корреляционной по контуру местности - TERCOM (англ. Terrain Contour Matching). Принцип действия состоит в том, что по фотоснимкам, выполненным с низкой опорной орбиты Земли, составляется трехмерный набор эталонных карт местности по маршруту полета ракеты, а бортовая РЛС обзора земной поверхности, проводя сканирование окружающего ее пространства, сопоставляет с введенной в ее программу картой и данным барометрического высотомера. Этот метод позволяет достаточно точно определить свое местоположение. Система дает крылатой ракете возможность летать на сверхмалых высотах и на высокой скорости огибать рельеф поверхности.

Электронно-оптическая корреляционная система - DSMAC (англ. Digital Scene Matching Area Correlator). В этой системе в качестве эталона используются цифровые картины предварительно отснятых районов местности по маршруту полета КР. Она позволяет существенно повысить точность стрельбы (КВО до 10 м). С внедрением в систему распознавания технологий нейронных сетей ожидается значительное повышение надежности системы (Крылатая ракета...).

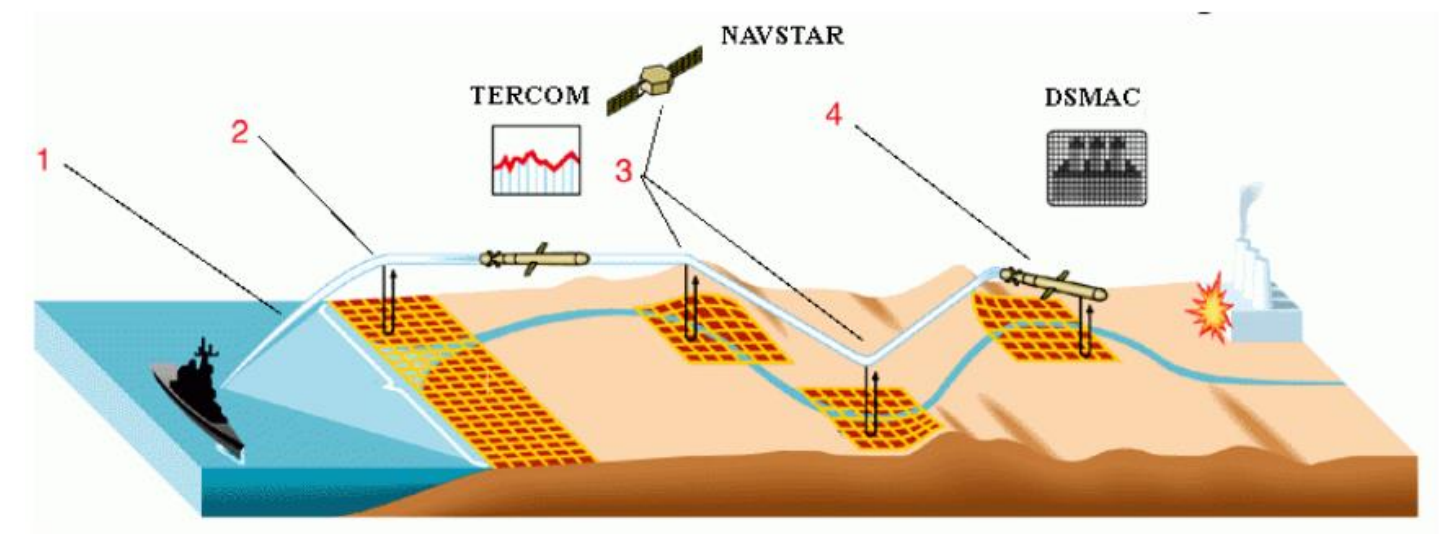

Рис. 3. Схема траектории полета ракеты «Tomahawk» BGM-109C/D: 1 - стартовый участок, выход на боевой курса; 2 - район первой коррекции по системе TERCOM; 3 - основной маршевый участок (совместное использование инерциальной системы ориентации, TERCOM и NAVSTAR/GPS); 4 - точное наведение на цель по системе DSMAC 


\section{Массированные удары крылатыми ракетами по военным и гражданским объектам в Сирийской арабской республике}

Уже второе десятилетие Министерством обороны США разрабатывается и практически реализуется военно-стратегическая концепция Глобального мгновенного удара PGS (англ. Prompt Global Strike), подразумевающая под собой синхронный удар неядерным оружием по ключевым объектам противника, уничтожение которых имеет решающее значение для перехвата стратегической инициативы.

Как всегда американцы решили отработать боевое применение новейшего оружия и боевой тактики на заведомо более слабом противнике, не способном адекватно ответить на агрессию симметричным ударом. Им, на самом деле, нужен был только повод, чтобы испытать в деле перспективную военную стратегию. В частности, нужно было отработать групповое взаимодействие и координацию большого числа ракет при нанесении массированного ракетного удара.

И повод и заведомо слабый противник нашлись быстро. Американцы, пользуясь безнаказанностью и грубой силой, решили наказать Башара Асада, используя мнимый предлог. 4 апреля 2017 г. в сирийском городе Хан-Шейхун в провинции Идлиб произошла атака нервнопаралитическим газом зарин против мирного населения. По данным Сирийского центра мониторинга по правам человека (SOHR) в результате инцидента за двое суток погибло 86 гражданских лиц, в их числе 30 детей и 20 женщин. Не было никаких объективных доказательств причастности к этой атаке ВС САР, однако Западные СМИ, политики и дипломаты резко и коллективно осудили действия сирийских военных, повесив на них всю ответственность за гибель мирного населения.

Утром 7 апреля 2017 г. по приказу президента США Дональда Трампа два американских эсминца USS «Ross» (DDG-71) и USS «Porter» (DDG-78) скоординировано выпустили 60 крылатых ракет по авиабазе Эш-Шайрат, где по мнению американского командования находились склады с химическими боеприпасами.

При этом американских генералов, отдававших приказ, не беспокоило то, что в случае действительного нахождения на базе запасов нервнопаралитических газов, таких как зарин, ракетный удар грозит реальной экологической и гуманитарной катастрофой с далеко идущими последствиями для всего ближневосточного региона в виде массовой гибели и химического отравления гражданского населения.

Удар был произведен. Сразу же после старта одна из ракет не раскрылась и утонула в море. Из 59 ракет до авиабазы Эш-Шайрат долетели 23 ракеты. Судьба остальных 36 ракет ни одной из сторон конфликта не разглашается. С большой вероятностью, они могли быть сбитыми, так и просто разбиться при полете на сверхмалых высотах. Маршрут ракет пролегал через горные районы Ливана и Сирии. Массовый полет крылатых ракет в таких жестких условиях выполнялся впервые. Во всех предшествующих эпизодах применения, «Томагавки» совершали полеты на относительно равнинной местности. Также среди многих военных экспертов высокие потери «Томагавков» могли быть обусловлены применением российских средств радиоэлектронной борьбы. Но скорее всего, имело место комплексное воздействие всех этих факторов. Так или иначе, ракеты до сирийской авиабазы долетели.

Бой с крылатыми ракетами должны были принять старые советские мобильные ЗРК 2К12 «Квадрат». Однако их станции обнаружения целей попросту не смогли увидеть «крадущиеся» на высотах до 50 м «Томагавки» и не сбили ни одной крылатой ракеты (ЗРК «Квадрат»...). Когда то ЗРК «Квадрат» отлично проявили свои боевые качества в войне Судного дня 1973 г., нанеся ощутимые потери ВВС Израиля, однако к настоящему моменту они устарели.

Несмотря на огромное количество выпущенных ракет, количество которых составляет 2 \% суммарного запаса всех стоящих на вооружении ВС США ракет «Томагавк», результат удара был скромный. На авиабазе были уничтожены от 6 до 20 самолетов, расположенных в бункерах; склады материально-технического обеспечения, столовая, учебный корпус и РЛС дальнего обнаружения. Взлетная полоса и рулежные дорожки остались целыми. Погибло 7 военных и 9 гражданских лиц. Суммарная стоимость выпущенных ракет оказалась выше, чем нанесенный ими ущерб. 


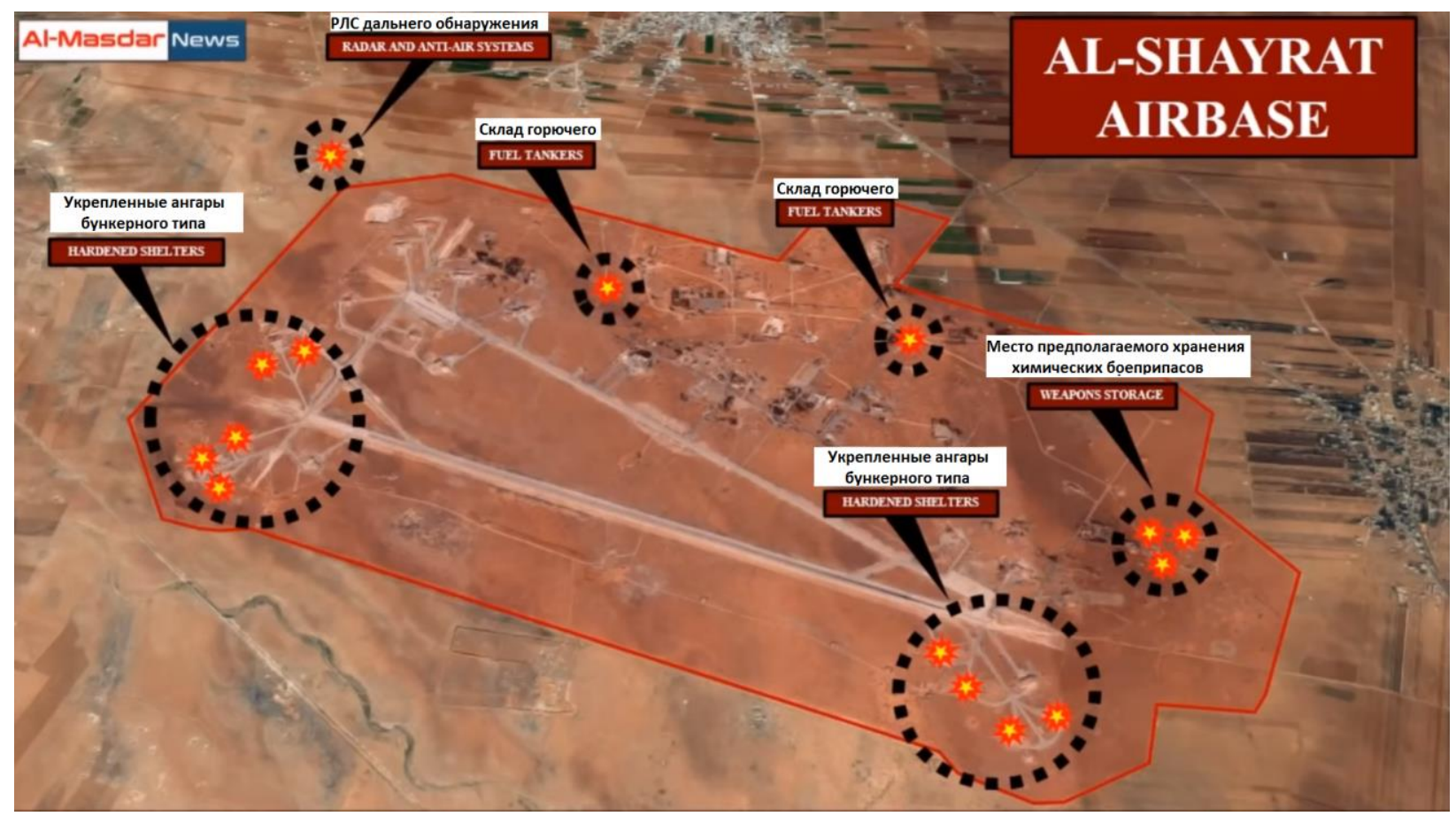

Рис. 4. Пораженные цели на Авиабазе «Шайрат»

Хоть удар по авиабазе и оказался неэффективен и нанес незначительные с военной точки зрения потери, в случае применения тактических ядерных боеприпасов последствия имели бы совершенно иной характер. Даже один достигший цели заряд мог бы уничтожить большую часть дислоцированных на авиабазе самолетов и на достаточно долгое время вывести ее из строя, образовав тем самым брешь в системе ПВО.

Помимо удара по авиабазе Эш-Шайрат силами западной коалиции проводились и другие массированные ракетные атаки.

14 апреля 2018 г. по военным и гражданским объектам в Сирии было выпущено уже более 100 ракет. И в этот раз новым предлогом стала химическая атака в г. Дума в восточной Гуте.

По данным Министерства обороны Российской Федерации целями атаки стали военные аэродромы Дювали, Блэй, Меззе, Хомс, Думейр и Эш-Шайрат, а также предполагаемые центры по разработке, производству и хранению химического оружия.

В частности, по данным МО РФ ракетному удару подверглась Авиабаза Думейр, дислоцированная на востоке от столицы Сирии города Дамаск. Все 12 ракет, выпущенных по авиабазе, были сбиты.

В этот день снова, второй раз, ночному ракетному подверглась удару и авиабаза «Шайрат». В налете участвовало 12 крылатых ракет. Атака была успешно отражена все 12 ракет, выпущенных по базе, были уничтожены.

В отражении атак на военные аэродромы и гражданские объекты участвовали в основном старые ЗРК советского производства 60-80-х гг. C-125, C-200 «Бук», «Квадрат» и «Оса». Их поддерживали новые Российские ЗРПК «Панцирь-С1». По словам представителя МО РФ Игоря Конашенкова «Панцири» выпустили 25 ракет, 23 из них достигли целей (Эффективность ЗРК...).

Самый сильный и концентрированный удар пришелся на НИИ Барзе, находящийся в столице Сирии. По мнению западных экспертов в этом засекреченном НИИ режимом Башара Асада разрабатывалось и производилось химическое оружие. По нему ВВС западной коалиции выпустили 30 ракет, из которых 23 поразили цель. Здание НИИ и прилегающие к нему постройки были уничтожены полностью. 


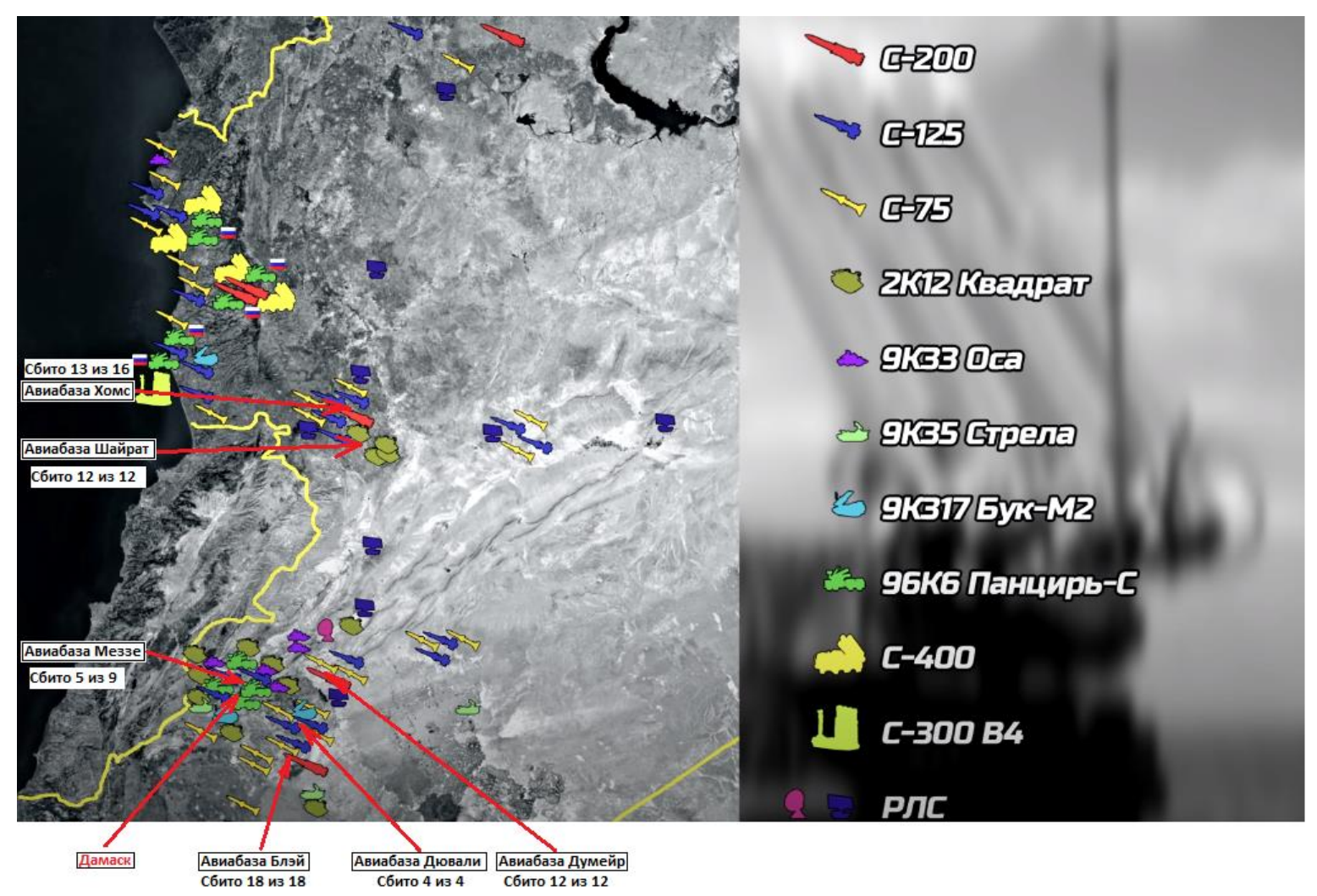

Рис. 5. Статистика эффективности отражения массированной ракетной 18 Апреля 2018 года на различные военные и гражданские объекты Сирийской Арабской Республики с дислокацией ЗРК (Интерактивная карта...).

\section{3. Заключение}

Борьба беспилотников и зенитно-ракетных комплексов это классический пример эволюционной борьбы средств нападения и защиты, как до этого была борьба снаряда и брони. В этой бесконечной гонке вот уже тысячелетие они совершенствуются и эволюционирюет по правилам естественного отбора.

И до недавнего времени ЗРК были доминирующей силой на поле боя. Однако опыт современных вооруженных конфликтов в Сирии, Ливии и Нагорном Карабахе показал, что даже самые современные российские системы ПВО последних модификаций несут неоправданно большие потери в боях с БПЛА.

Неутешительной также является тенденция, что крылатые ракеты и БПЛА как средство нападения дешевеют, a в их конструкцию внедряются элементы роботизированного управления темпами, намного более быстрыми, чем в ЗРК. Причиной тому - объективная реальность: ЗРК как средство обороны на порядок сложнее, чем, к примеру, противорадиолокационная ракета, радиоуправляемый самолет или барражирующий боеприпас с камерой. Тенденция сводится к тому, что высокоточное оружие станет массовым и приобретет автономный коллективный разум.

Со временем мы столкнёмся с ситуацией, когда дорогие в производстве и обслуживании ЗРК будут нести еще большие потери в боях против недорогих беспилотников и крылатых ракет.

\section{Литература}

«Уроки» ракетного удара... - «Уроки» ракетного удара США по территории Сирии как бороться с крылатыми ракетами? // Информационный портал Новый оборонный заказ. [Электронный pecypc]. URL: https://dfnc.ru/c106-technika/uroki-raketnogo-udara-ssha-po-ter ritorii-sirii-ili-kak-borotsya-s-krylatymi-raketami 
В Ливии... - В Ливии российскими ЗРПК «Панцирь-С1» сбиты 47 турецких БПЛА Bayraktar TB2 // Информационный портал NR. [Электронный ресурс]. URL: https://newsr.ru/news/politics/503576/

ЗРК «Квадрат»... - ЗРК «Квадрат» не увидели американские «Томагавки» // Информационный портал Военное обозрение. [Электронный pecypc]. URL: https://topwar.ru/ 113366-zrk-kvadrat-ne-uvideli-amerikanskie-tomagavki.html

Интерактивная карта... - Интерактивная карта боевых действий Military Maps. [Электронный ресурc]. URL: https://militarymaps.info/Ydx_sub/Ydx_subscription.php

Крылатая ракета... - Крылатая ракета «Томагавк» A/C/D // Информационный портал Ракетная техника. [Электронный ресурc]. URL: https://missilery.info/missile/bgm1ogc-d

Почему большинство... - Почему большинство «умных» ракет США не достигли целей в Сирии // Информационный портал Russia Today. [Электронный pecypc]. URL: https://russian.rt.com/world/article/503506-siriya-udar-sovetskie-pvo

Почему Панцири... - Почему Панцири несут потери в Ливии ? // Информационный портал Звезда. [Электронный ресурс]. URL: https://zvezdaweekly.ru/news/20206151625-rTG2 W.html

Стало известно... - Стало известно о массовой атаке 20 Турецких Bayraktar на Российский «Панцирь» Информационный портал Lenta.ru. [Электронный pecypc]. URL: https://lenta.ru/news/2021/o3/o9/bayraktar

Турецкий БПЛА - Турецкий БПЛА Bayraktar TB2: История создания, конструкция, технические характеристики, опыт боевого применения // Информационный портал Мировое обозрение. [Электронный ресурс]. URL: https://tehnowar.ru/182574-Tureckiy-BPLA-BayraktarTB2-istoriya-sozdaniyakonstrukciyatehnicheskie-harakteristikiopyt-boevogo-primeneniya.html

Удар по России... - Удар по России: Миф или реальность? // Информационный портал Национальная оборона. [Электронный ресурc]. URL: https://oborona.ru/includes/periodics/ maintheme/2011/0516/22236162/detail.shtml.

Эффективность ЗРК... - Эффективность ЗРК в отражении ракетного удара 18 апреля 2018 года // Информационный портал Министерства обороны Российской Федерации. [Электронный ресурc]. URL: https://function.mil.ru/news_page/country/more.htm?id=1217 1611@e gNews

\section{References}

«Uroki» raketnogo udara... - "Lessons" of a US missile strike on Syrian territory how to deal with cruise missiles? // Information portal New defense order. [Electronic resource]. URL: https://dfnc.ru/c106-technika/uroki-raketnogo-udara-ssha-po-territorii-sirii-ili-kak-borotsya-skrylatymi-raketami

Effektivnost' ZRK... - The effectiveness of the air defense system in repelling a missile strike on April 18, 2018 // Information portal of the Ministry of Defense of the Russian Federation. [Electronic resource]. URL: https://function.mil.ru/news_page/country/more.htm?id=12171611@egNews

Interaktivnaya karta... - Interactive map of military operations Military Maps. [Electronic resource]. URL: https://militarymaps.info/Ydx_sub/Ydx_subscription.php

Krylataya raketa... - Tomahawk cruise missile A / C / D. Information portal Missile technology. [Electronic resource]. URL: https://missilery.info/missile/bgm109c-d.

Pochemu bol'shinstvo... - Why the majority of US "smart" missiles did not reach their targets in Syria. Information portal Russia Today. [Electronic resource]. URL: https://russian.rt.com/ world/article/503506-siriya-udar-sovetskie-pvo

Pochemu Pantsiri... - Why are the Shells suffering losses in Libya? Information portal Zvezda. [Electronic resource]. URL: https://zvezdaweekly.ru/news/20206151625-rTG2W.html

Stalo izvestno... - It became known about the mass attack of 20 Turkish Bayraktar on the Russian "Pantsir" Information portal Lenta.ru. [Electronic resource]. URL: https://lenta.ru/news/ 2021/03/o9/bayraktar

Turetskii BPLA - Turkish UAV Bayraktar TB2: History of creation, design, technical characteristics, experience of combat use. Information portal World Review. [Electronic resource]. URL: https://tehnowar.ru/182574-Tureckiy-BPLA-Bayraktar-TB2-istoriya-sozdaniyakonstrukciyat ehnicheskie-harakteristikiopyt-boevogo-primeneniya.html 
Udar po Rossii... - Strike against Russia: Myth or Reality? Information portal National Defense. [Electronic resource]. URL: https://oborona.ru/includes/periodics/maintheme/2011/0516/22 236162/detail.shtml

V Livii... - In Libya, 47 Turkish Bayraktar TB2 UAVs were shot down by Russian "Pantsir-S1" air defense missile systems. Information portal NR. [Electronic resource]. URL: https://newsr.ru/news/politics/503576/

ZRK «Kvadrat»... - SAM "Kvadrat" did not see the American "Tomahawks" // Information portal Voennoye Obozreniye. [Electronic resource]. URL: https://topwar.ru/113366-zrk-kvadratne-uvideli-amerikanskie-tomagavki.html

\section{Опыт боевого применения беспилотных аппаратов в конфликтах последнего времени по данным электронных СМИ}

Ирек Азатович Соловатов а

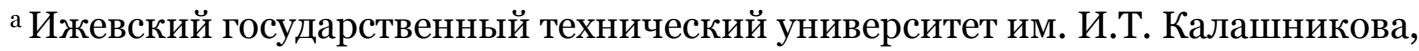
Российская Федерация

Аннотация. На данный момент беспилотные летательные аппараты представляют собой активно развивающуюся систему вооружений, возможно в ближайшем будущем сформирующуюся в новый род войск. Отсутствие пилота позволяет не только уменьшить массу и габариты аппарата, но и снизить его стоимость. А оператор, находящийся на земле получает возможность совершать намного более дерзкие опасные действия, по сравнению с пилотируемыми аппаратами.

В работе дается обзор особенностей и результатов боевого применения беспилотных летательных аппаратов в вооруженных конфликтах последнего времени. Дается описание турецкого БПЛА «Bayraktar» и носимых им боеприпасов. В конспективной форме приведены результаты его применения его в конфликте в Нагорном Карабахе, операции «Весенний щит» и гражданской войне в Ливии. Дается описание крылатой ракеты «Томагавк» и результаты ее применения в Сирии. Работа написана по данным электронных средств массовой информации, находящихся в открытом доступе.

Ключевые слова: конфликт, боевой опыт, зенитно-ракетный комплекс, беспилотный летательный аппарат. 